\title{
Allometric models for estimating the aboveground biomass of the mangrove Rhizophora mangle
}

\author{
Heide Vanessa Souza Santos ${ }^{1 *}$, Francisco Sandro Rodrigues Hollanda ${ }^{1}$, Tiago de Oliveira Santos ${ }^{l}$, \\ Karen Viviane Santana de Andrade ${ }^{l}$, Mykael Bezerra Santos Santanal, Gustavo Calderucio Duque \\ Estrada ${ }^{2}$, Mario Luiz Gomes Soares ${ }^{2}$
}

\author{
${ }^{1}$ Laboratorio de Erosão e Sedimentação- Universidade Federal de Sergipe \\ (Av. Mal. Rondon, s/n, Jardim Rosa Elze, São Cristovão, SE, CEP: 49.100.000) \\ ${ }^{2}$ Núcleo de Estudos em Manguezais - Faculdade de Oceanografia Universidade do Estado do Rio de Janeiro, Campus Maracanã \\ (Rua São Francisco Xavier, 524, Sala 4023-E, Pavilhão João Lyra Filho)
}

*Corresponding author: heidee.vanessa@gmail.com

\section{ABSTRACT}

The development of species-specific allometric models is critical to the improvement of aboveground biomass estimates, as well as to the estimation of carbon stock and sequestration in mangrove forests. This study developed allometric equations for estimating aboveground biomass of Rhizophora mangle in the mangroves of the estuary of the São Francisco River, in northeastern Brazil. Using a sample of 74 trees, simple linear regression analysis was used to test the dependence of biomass (total and per plant part) on size, considering both transformed (ln) and not-transformed data. Best equations were considered as those with the lowest standard error of estimation (SEE) and highest adjusted coefficient of determination $\left(\mathrm{R}^{2}{ }_{\mathrm{a}}\right)$. The $\mathrm{ln}$ transformed equations showed better results, with $\mathrm{R}^{2}$ near 0.99 in most cases. The equations for reproductive parts presented low $\mathrm{R}^{2}$ values, probably attributed to the seasonal nature of this

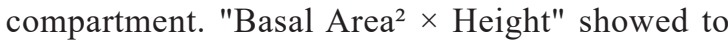
be the best predictor, present in most of the bestfitted equations. The models presented here can be considered reliable predictors of the aboveground biomass of $R$. mangle in the NE-Brazilian mangroves as well as in any site were this widely distributed species present similar architecture to the trees used in the present study.

Descriptors: Allometric equations, Aboveground biomass, Mangrove, Regression analysis, Rhizophora mangle.

\section{RESUMO}

O desenvolvimento de modelos alométricos espécie-específicos é fundamental para a melhoria das estimativas de biomassa aérea, bem como para a estimativa do estoque e sequestro de carbono em florestas de mangue. Este estudo desenvolveu equações alométricas para estimar a biomassa aérea de Rhizophora mangle nos manguezais do estuário do rio São Francisco, nordeste do Brasil. Usando uma amostra de 74 árvores, análises de regressão linear simples foram usadas para testar a dependência da biomassa (total e por parte da planta) do tamanho, considerando dados transformados (Ln) e não transformados. As melhores equações foram aquelas com menor erro padrão da estimativa (SEE) e maior coeficiente de determinação ajustado $\left(\mathrm{R}_{\mathrm{a}}^{2}\right)$. As equações $\ln$-transformadas apresentaram melhores resultados, com $\mathrm{R}^{2}$ próximo a 0,99 na maioria dos casos. As equações para partes reprodutivas apresentaram valores baixos de $\mathrm{R}^{2}{ }_{\mathrm{a}}$ o que pode ser atribuído ao caráter sazonal deste compartimento. "Área basal ${ }^{2} \times$ Altura" demonstrou ser o melhor preditor, presente na maioria das equações melhor ajustadas. Os modelos aqui apresentados podem ser considerados preditores confiáveis da biomassa aérea de $R$. mangle no manguezal do Nordeste brasileiro, bem como em qualquer local onde esta espécie de ampla distribuição assemelhe-se à arquitetura das árvores utilizadas no presente estudo.

Descritores: Equações alométricas, Biomassa aérea, Manguezal, Análises de regressão, Rhizophora mangle. 


\section{INTRODUCTION}

Mangroves stand out for being present throughout most of the tropical and subtropical coasts of the globe (DUKE et al., 2002). Its strategic position at the interface between terrestrial and marine environments gives it characteristics and adaptations that are not found in any other tropical ecosystem (ALONGI, 2009). This ecosystem also represents an important source of carbon and nutrients to benthic and pelagic biota of coastal regions (ABOHASSAN et al., 2012).

There is a growing interest in studies on biomass and carbon stock estimation in forests due to the possibility of offsetting greenhouse gas emissions (SIIKAMÄKI et al., 2012) and the necessity of determining the potential emission of carbon released into the atmosphere due to deforestation and changes in land use (LU et al., 2002). In this context, the role of mangrove forests in the process of global warming mitigation has been recently highlighted by some authors (DONATO et al., 2011; McLEOD et al., 2011). These authors showed that mangroves are hotspots of carbon, presenting four times higher carbon stock and ten times higher carbon sequestration (in the soil) than terrestrial forest ecosystems.

Studies on quantification of forest aboveground biomass are divided in direct methods (actual measurement of all plant biomass in a known area) and indirect methods, for example those based on allometric models developed from trees with known size and mass (SILVEIRA et al., 2007; BURGER; DELITTI, 2008). The latter stands out among all methods as it ensures high precision and accuracy while preventing the clearing of large forested areas (CHANDRA et al., 2011). Moreover, in the case of mangrove forests, this method is even more advisable, given the reduced number of species compared to terrestrial tropical forests, which makes it easier to develop allometric models for each species, location, and architecture (BROWN, 2002).

Several allometric equations have been developed to assess the aboveground biomass in mangroves species (KOMIYAMA et al., 2008), including Rhizophora mangle L., a dominant and widely distributed species in the Atlantic and East Pacific (AEP) region, from Florianópolis/Brazil to Florida/USA (DUKE, 1992; SOARES et al., 2012). The existing specific models for this species are highly concentrated in the transition between tropical and subtropical regions $\left(20-25^{\circ} \mathrm{N}\right.$ and $\left.\mathrm{S}\right)$, in Rio de Janeiro/Brazil (SOARES;
SCHAEFFER-NOVELLI, 2005), Dominican Republic (SHERMAN et al., 2003), Hawaii/USA (COX; ALLEN, 1999) and Florida/USA (ROSS et al., 2001; SMITH III; WHELAN, 2006), where trees are low- to mid-developed (TWILLEY et al., 1992), with similar architecture. A vast latitudinal range of distribution $\left(0^{\circ}-\right.$ $20^{\circ} \mathrm{N}$ and $\mathrm{S}$ ) is covered by only two studies, FROMARD et al. (1998) and MEDEIROS; SAMPAIO (2008). The former was developed in French Guiana and is the only reference that present models for the maximumdeveloped trees found in the Amazonian mangroves; the latter was developed in Itamaracá Island (Pernambuco, Northeastern Brazil; $8^{\circ} \mathrm{S}$ ) and its models could be considered representative of high developed trees of R. mangle in the AEP mid-tropical region $\left(5-15^{\circ} \mathrm{S} / \mathrm{N}\right)$. However, the models from MEDEIROS; SAMPAIO (2008) are size-limited (diameter $<20 \mathrm{~cm}$; height $<15$ $\mathrm{m})$ and don't cover the full size range presented by $R$. mangle in the AEP mid-tropical region (diameter: up to 40-50 cm; height: up to 25-30 m).

Due to the low representativeness of existing models, the objective of this study was to develop allometric models to estimate the aboveground biomass of $R$. mangle in the mangroves of the AEP mid-tropical region.

\section{MATERIAL AND METHODS}

\section{STUdy AREA}

This study was conducted in the estuarine region of the São Francisco River (1050' S, 36 $44^{\circ}$ 'W), which comprises an area of approximately 3531.16 ha (35.31 $\mathrm{km}^{2}$ ) covered by mangrove forests (Figure 1). The studied area is crossed by a network of tidal channels fringed by mangrove forests characterized by a high structural variability, with average height and diameter at breast height $(\mathrm{DBH})$ ranging from 4.34 to $8.36 \mathrm{~m}$ and 4.59 to $8.66 \mathrm{~cm}$, respectively (SANTOS et al., 2012). These mangrove forests are composed by Avicennia schaueriana, A. germinans, Laguncularia racemosa and $R$. mangle, with the later species being the dominant one (relative dominance $>60 \%$ ) (SANTOS et al., 2012).

The climate is classified as Tropical/Megathermal humid to sub-humid, according to the Köppen classification, with an annual average temperature of $25.7^{\circ} \mathrm{C}$. The average annual rainfall is $1201.7 \mathrm{~mm}$, with a rainy season occurring between the months of March and August. The area is subjected to a mesotidal regime, with a semi-diurnal tidal frequency. 


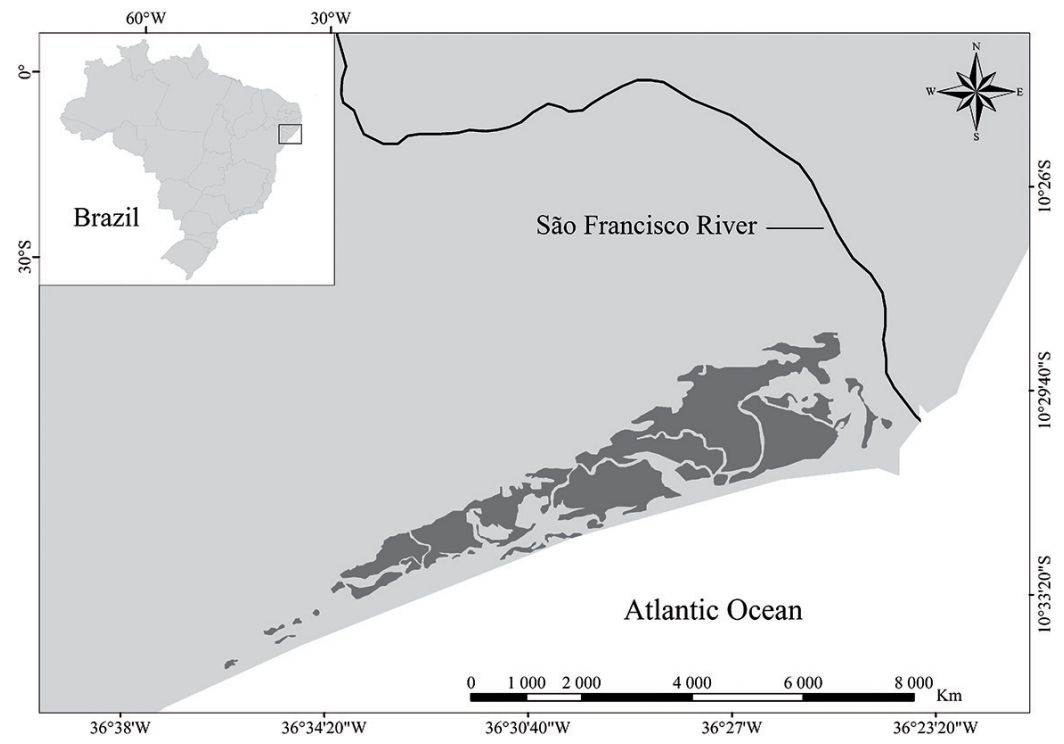

Figure 1. Map of the study area (Datum WGS 84). Mangrove cover was obtained from the database of the Brazilian Ministry of the Environment and is indicated with dark grey.

\section{SAMPLING DESIGN}

The sampling method was adapted from SCHAEFFERNOVELLI; CINTRÓN (1986), SOARES; SCHAEFFERNOVELLI (2005), BURGER; DELITTI (2008), and SAMPAIO et al. (2010).

Seeking to achieve a balance between sample representativeness per size range, the sampling effort needed to collect each individual, the negative impact caused by the felling of larger trees and the positive impact of the inclusion of a greater number of individuals in model fitting, the following sampling strategy was defined: 1) $\mathrm{DBH}<13 \mathrm{~cm}$ : four trees per $1-\mathrm{cm}$ class; 2) $\mathrm{DBH}>13.1 \mathrm{~cm}$ : two trees per $2-\mathrm{cm}$ class. The higher size class as defined based on the phytosociological assessment of SANTOS et al. (2012). Based on this sampling strategy, 74 trees were felled. For each tree, the following variables were measured before sampling: diameter at breast height or above the highest prop root; height; mean diameter of the crown; and crown area, which was determined assuming an elliptical shape, as follows: crown area $=(\pi$ $\left.\times d_{1} \times d_{2}\right) / 4$, where $\mathrm{d}_{1}$ and $\mathrm{d}_{2}$ are the ellipse diameters measured by crown projection on the ground (SOARES; SCHAEFFER-NOVELLI, 2005).

After size measurements, the trees were felled. To measure the fresh biomass, each tree was separated manually into the following compartments (plant parts): leaves (including buds and stipules); reproductive parts (flowers, fruits, and propagules); twigs (diameter $<2.5$ $\mathrm{cm}$ ); branches (diameter $>2.5 \mathrm{~cm}$ ); main branches; trunk; and prop roots. Main branches were sampled when the tree presented bifurcation right after the highest stilt root, but as long as the branches had similar sizes (SOARES; SCHAEFFER-NOVELLI, 2005). All material was weighed in the field with dynamometer-type scales. Subsamples of each compartment were taken to the laboratory to determine their dry weights.

\section{Sample Processing and Statistical Treatment of Data}

After the determination of the fresh mass, the subsamples of each compartment were dried for 15 days at $70^{\circ} \mathrm{C}$. The dry weights of the samples were determined by precision scales $(0.01 \mathrm{~g})$. Simple linear regression analysis, using the STATISTICA 7.0 software and considering a significance level of $1 \%$, was applied to determine the relationship between dry weights (dependent variable) and fresh weights (independent variable) of each compartment. The dry mass of each compartment was obtained by applying the fresh mass obtained in the field to the regression equations. The dry mass of the whole tree was then obtained by summing the dry mass of each compartment.

The allometric models were also fitted by simple linear regression analysis, testing the dependence of dry mass on size (independent) variables. The models were tested using both ln-transformed and not-transformed 
data. The independent variables were defined according to SOARES; SCHAEFFER-NOVELLI (2005) and are presented in Table 1.

As dependent variables, in addition to those aforementioned, the following combinations of compartments were used according to the guidelines of SOARES; SCHAEFFER-NOVELLI (2005):

a) Green parts (Leaves + Reproductive parts);

b) Crown 1 (Leaves + Reproductive parts + Branches);

c) Crown 2 (Leaves + Reproductive parts + Twigs + Branches);

d) Crown 3 (Leaves + Reproductive parts + Branches + Main Branches);

e) Trunk + Main Branches;

f) Woody parts (Twigs + Branches + Main Branches + Trunk + Prop Roots);

g) Aerial parts (Total - Prop roots).

In the evaluation of the models, the basic assumptions of simple linear regression analysis were checked according to the recommendations of ZAR (2010); DRAPER; SMITH (1998). Normality and homogeneity of variances were verified for each regression by residual analysis. The significance of each regression was evaluated by analysis of variance (ANOVA). The statistically significant regressions that met the assumptions of the test were analyzed for goodness of fit by calculating the $\mathrm{R}^{2}$ (adjusted coefficient of determination), for precision (standard error of estimation - SEE), and through graphical analysis of the dispersions.

Following the studies of BROWN et al. (1989), BROWN et al. (1997), ONYEKWELU (2004), SAH et al. (2004) and SOARES; SCHAEFFER-NOVELLI (2005), the criteria for selecting the best models were (a) highest $\mathrm{R}^{2}{ }_{\mathrm{a}}$, (b) lowest SEE, and (c) best graphical distribution of absolute residual values.

\section{RESULTS}

Seventy four trees were sampled, with DBH and height ranging from 0.95 to $39.18 \mathrm{~cm}$ and 0.74 to 22.52 $\mathrm{m}$, respectively. The regressions between dry and fresh weights per compartment are all significant (Table 2) and presented $\mathrm{R}^{2}$ between 0.91 and 0.97 , which suggests good fit of the equations. The dry weights of each tree (and its compartments) were thus estimated by applying the fresh weights to these regression equations. Considering all the combinations of dependent and independent variables and the two types of equations (ln-transformed or not), 375 linear allometric equations were tested. Most of the equations were significant $(p<0.01)$, except for reproductive parts, which presented some equations that were not significant. The residual analysis showed that only the models that were under logarithmic transformation met the assumptions of normality and homoscedasticity. More than not meeting the assumptions of normality and homoscedasticity, most non-transformed equations presented an arc-shaped distribution of residuals, which is an indication that a curvilinear relationship between dependent and independent variables should be considered instead of a linear one (see ZAR, 2010). Nevertheless, in some cases the residuals of non-transformed equations presented a combination between arc-shaped distribution and a pattern characterized by the increase of the residuals variance with the increase of the independent variable, which indicates heteroscedasticity (i.e. Figure 2). On the other hand, log-transformed equations presented residuals that were linearly distributed over the independent variable range, as demonstrated by the best-fit equations, indicating homoscedasticity (Figure 3). Log-transformed equations also showed better adjustment and lower standard errors. As a result, non-logarithmic equations were discarded.

The coefficients of determination $\left(\mathrm{R}_{\mathrm{a}}^{2}\right)$ and the standard errors of estimation (SEE) of all the logtransformed equations are presented in Table 3. Based on these results, the best allometric models by compartment and combination of compartments were determined and are presented in Table and Figure 4. The best models, the ones with the lowest SEE, also presented the highest $\mathrm{R}_{\mathrm{a}}^{2}$. These models have coefficients of determination greater than 0.90 in most cases, except for main branches and

Table 1. Independent variables used to estimate the biomass of $R$. mangle according to the type of model. Legend: DBH in $\mathrm{cm}$; Height in $\mathrm{m}$; Crown area in $\mathrm{m}^{2}$; Crown diameter in $\mathrm{m}$; Basal Area in $\mathrm{m}^{2}$.

\begin{tabular}{|c|c|}
\hline Type of Model & Independent Variables (x) \\
\hline$y=a+b x$ & 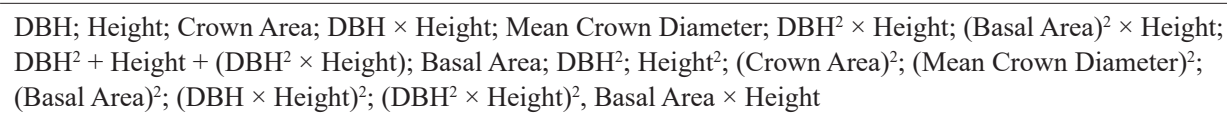 \\
\hline $\ln (y)=a+b \ln (x)$ & $\begin{array}{l}\mathrm{DBH} ; \text { Height; Crown Area; DBH } \times \text { Height; Mean Crown Diameter; DBH } 2 \times \text { Height; }(\text { Basal Area })^{2} \times \text { Height; } \\
\mathrm{DBH}^{2}+\text { Height }+\left(\mathrm{DBH}^{2} \times \text { Height }\right)\end{array}$ \\
\hline
\end{tabular}


Table 2. Regressions between dry weights $(\mathrm{g})$ and fresh weights $(\mathrm{g})$ for each compartment of $R$. mangle. Legend: $\mathrm{n}=$ sample size; $y=$ dry weight; $\mathrm{x}=$ fresh weight; $\mathrm{R} 2 \mathrm{a}=$ Adjusted Coefficient of Determination; $\mathrm{Sb}=\mathrm{Standard}$ error of the coefficient of regression; $\mathrm{SEE}=\mathrm{Standard}$ Error of Estimation; $* *=\mathrm{p}<0.01$.

\begin{tabular}{lccccc}
\hline Compartment & $\mathrm{N}$ & Equation & $\mathrm{R}^{2}$ & $\mathrm{Sb}$ & $\mathrm{SEE}$ \\
\hline Trunk & 74 & $y=0.651467(x)^{* *}$ & 0.97 & 0.009046 & 394.005 \\
Branches and Twigs & 74 & $y=0.479409(x)^{* *}$ & 0.94 & 0.013583 & 124.632 \\
Leaves & 74 & $y=0.351908(x)^{* *}$ & 0.91 & 0.012867 & 161.0216 \\
Reproductive parts & 42 & $y=0.335009(x)^{* *}$ & 0.96 & 0.010922 & 423.4881 \\
Prop Roots & 74 & $y=0.443327(x)^{* *}$ & 0.93 & 0.014143 & 450.6888 \\
\hline
\end{tabular}

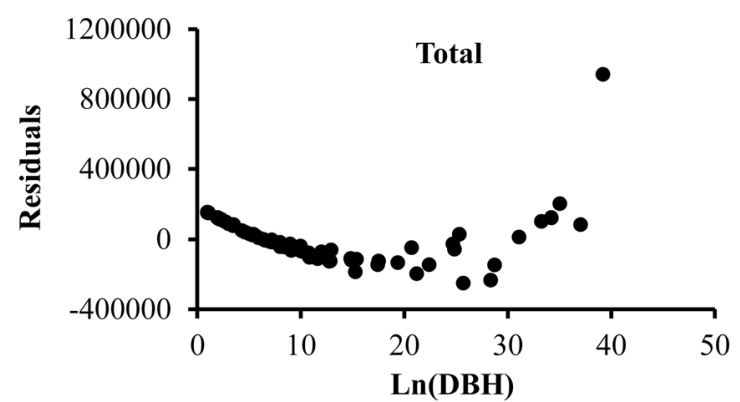

Figure 2. Residuals distribution for the relationship between total biomass and $\mathrm{DBH}$.

reproductive parts, which showed maximum $\mathrm{R}_{\mathrm{a}}^{2}$ values of 0.85 and 0.43 , respectively. The lower sample size for these compartments (main branches $=60$; reproductive parts $=43$ ) are probably one of the causes of this pattern, but seasonality may also play a role, as will be discussed in the next section.

Combinations of compartments showed high values of $\mathrm{R}_{\mathrm{a}}^{2}$ (see Tables 3 and 4), such as those related to aerial parts $\left(\mathrm{R}_{\mathrm{a}}^{2}=0.99\right)$ and woody parts $\left(\mathrm{R}_{\mathrm{a}}^{2}=0.99\right)$, and may be considered good alternatives for estimating the biomass of the plant portions. In terms of independent variables, "Basal Area ${ }^{2} \times$ Height" and "DBH ${ }^{2} \times$ Height", which simulate volume measures, stood out for generating the best equations for most of the dependent variables (Table 4). On the other hand, "Height", "DBH $\times$ Height" and the variables related to measurements of the crown (mean diameter and area) had generally higher SEE and lower $\mathrm{R}_{\mathrm{a}}^{2}$ (Table 3) and were not related to any of the best-fit equations.

Considering, that DBH is more easily measured at the field and may have higher precision in forestry inventories then height, allometric equations considering only DBH as the predictor variable are alternatively presented in Table 5 and Figure 4 for practical reasons.

\section{DISCUSSION}

The fact that some equations tested for reproductive parts were not significant is probably explained by the seasonal nature of reproduction of this species (FERNANDES, 1999), which led to the sampling of trees in different phases of the reproduction cycle and thus with different proportions of reproductive tissues. Similar results were also obtained by SOARES; SCHAEFFERNOVELLI (2005) for $R$. mangle and by ESTRADA et al. (2014) for A. schaueriana. Thus, considering that this factor would affect the variability of the biomass in that compartment, sampling should have always been done during the same reproductive phase, which would result in a logistically unfeasible sampling strategy.

It was found that the models with the greatest $\mathrm{R}^{2}$ values showed the lowest SEEs for all compartments, including total biomass, unlike SOARES; SCHAEFFERNOVELLI (2005), who found lower SEEs for some models that did not present maximum $\mathrm{R}_{\mathrm{a}}^{2}$. Considering that the development of allometric models for biomass estimation assumes minimization of errors and maximized accuracy, it is desirable that the selected models present minimum $\mathrm{SEE}$ and maximum $\mathrm{R}^{2}$ values. As presented before, the models that were under logarithmic transformation were the only ones to meet the assumptions of normality and homogeneity of variances and they also showed better adjustment and lower standard errors, which is in agreement with the findings of CLOUGH; SCOTT (1989), ONG et al. (2004), COMLEY; MAcGUINNESS (2005) and HOSSAIN et al. (2008). This pattern explains why the non-transformed equations were discarded from the analysis.

The lower $\mathrm{R}_{\mathrm{a}}{ }_{\mathrm{a}}$ values for main branches and reproductive parts may reflect the smaller sample sizes for these compartments, as mentioned before by SOARES; 


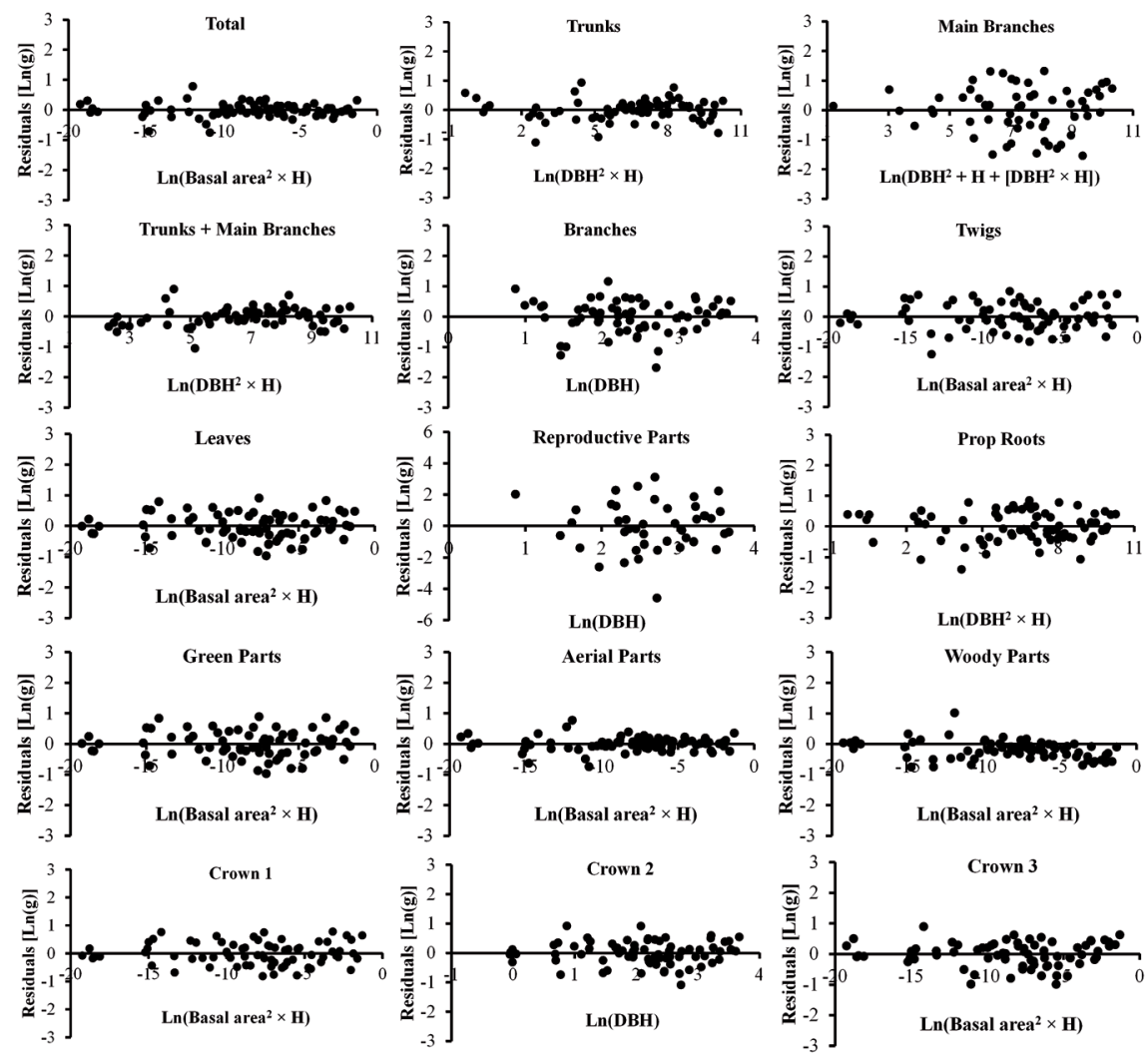

Figure 3. Residuals distribution for the best log-transformed equations (see Table 4).

SCHAEFFER-NOVELLI (2005) and ESTRADA et al. (2014), who found similar results for these compartments. For the reproductive parts, it should also be noted the seasonal behavior of this species with respect to its reproduction, as discussed earlier.

It was found that the grouping of compartments was advantageous in order to obtain equations for estimating the biomass of the plant portions, since they showed high values of $\mathrm{R}^{2}$ (Table 4 ), such as those related to aerial parts $\left(\mathrm{R}_{\mathrm{a}}^{2}=0.99\right)$ and woody parts $\left(\mathrm{R}_{\mathrm{a}}^{2}=0.99\right)$. The grouping of compartments showed to be a good way of minimizing the variances, the examples being reproductive parts and main branches, which presented increased adjustments when associated to other compartments than individually (Table 4).

Although DBH is generally the most common independent variable found in the available allometric models (CLOUGH; SCOTT, 1989; FROMARD et al., 1998; COMLEY; McGUINNESS, 2005; KOMYIAMA et al., 2008), it was observed that the equations based on "Basal Area ${ }^{2} \times$ Height" and "DBH ${ }^{2} \times$ Height" presented higher $\mathrm{R}^{2}$ in most of the best equations in the present study. Other studies have also found good fits with these variables, such as TAMOOH et al. (2009), for R. mucronata in Gazi Bay (Kenya), SOARES; SCHAEFFER-NOVELLI (2005) for $R$. mangle and ESTRADA et al. (2014) for $A$. schaueriana in Guaratiba (Rio de Janeiro, Brazil), and MURALI et al. (2005), for deciduous species tropical forests. However, considering the recommendations of BURGER; DELITTI (2008), who claim that models using $\mathrm{DBH}$ as the independent variable have the advantages of being easily measured and having higher precision of measurement in the field, equations considering only $\mathrm{DBH}$ are, alternatively, presented in Table 5.

The analysis of the data in Table 5 shows that the values of $\mathrm{R}^{2}$ and SEE of these models are always very close to those observed for the best models (Table 4). Therefore, it is possible that the balance between the highest measurement error of height compared to $\mathrm{DBH}$ and the lowest errors of the models that include height as a part of the variable may favor the models that use only DBH. This hypothesis, however, must be considered carefully in future studies. 
Table 3. Adjusted coefficients of determination $\left(\mathrm{R}_{\mathrm{a}}^{2}\right)$ and standard error of estimation (SEE) for all log-transformed regression analyses.

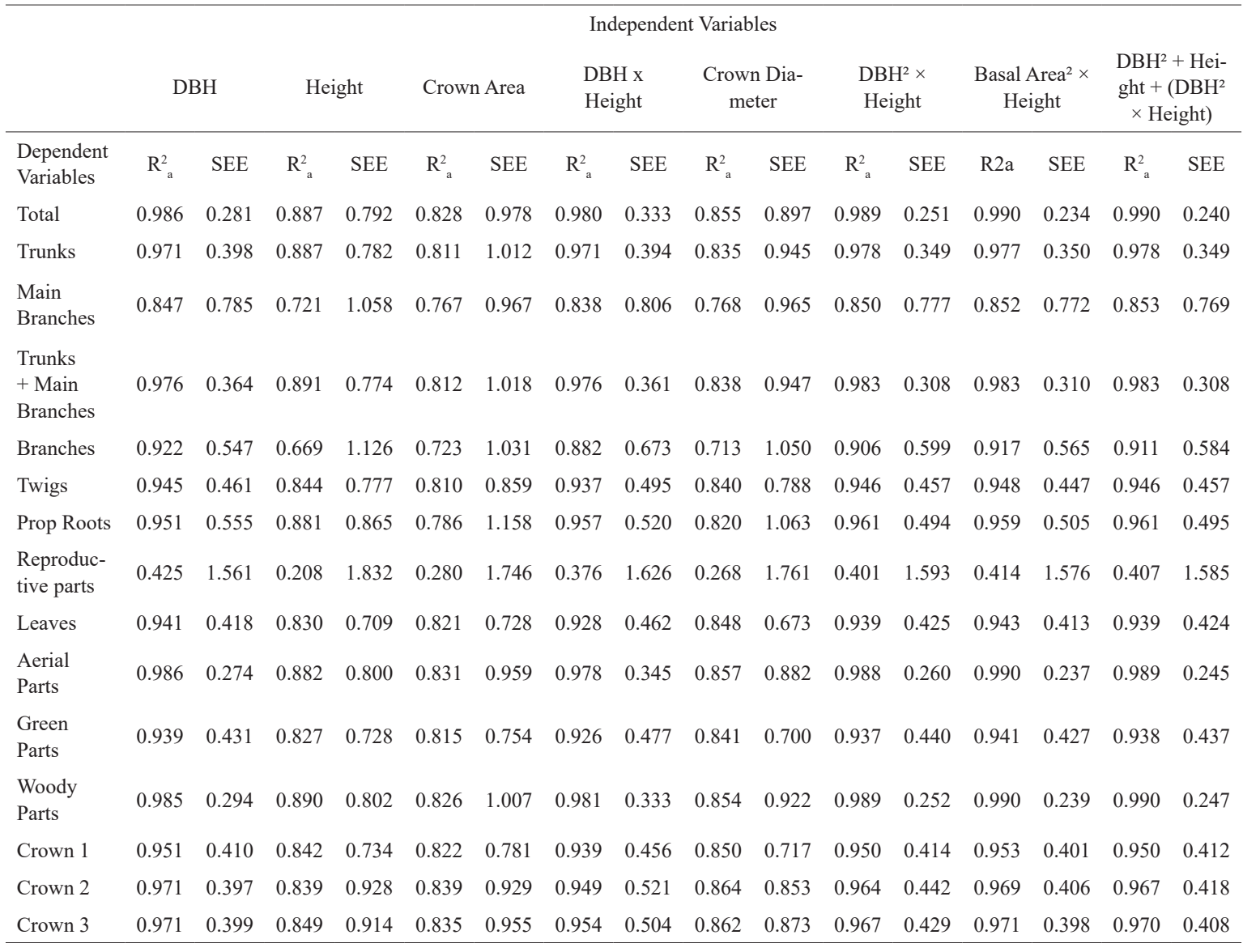

The $\mathrm{R}_{\mathrm{a}}^{2}$ of the selected equations produced in the present study are higher than those observed by MEDEIROS; SAMPAIO (2008) for the same species in the mangroves of Itamaracá (Pernambuco, Brazil $7^{\circ} \mathrm{S}$ ): leaves $=0.83$; branches $=0.90$; trunk $=0.89$; prop roots $=0.85$; total $=0.94$. This difference is probably due to the higher sampling effort used in this study, since MEDEIROS; SAMPAIO (2008) used a smaller sample size (36 individuals, against 74 individuals in this study) and sampled trees with smaller diameter (2.5 to $20.7 \mathrm{~cm}$ ) and height $(1.8$ to $14.0 \mathrm{~m})$ ranges. Therefore, given the greater accuracy and representativeness in terms of size amplitude, the models developed in this study are more suitable for estimating the aboveground biomass of $R$. mangle in Northeastern Brazilian mangroves as well as in other regions with a similar environmental setting in the mid-tropical $\left(5-15^{\circ} \mathrm{S}\right.$ and $\left.\mathrm{N}\right)$ coasts of the Atlantic and East Pacific region.
The logarithmic models generated the best fits for the relationships between biomass and the independent variables. The selected independent variables for this study explained, in most cases, over $90 \%$ of the variability of the aboveground biomass of $R$. mangle trees. The variables Basal Area ${ }^{2} \times$ Height, and $\mathrm{DBH}^{2} \times$ Height, led to equations with the lowest SEEs and the best fits in most compartments.

The models produced in this study are expected to enable estimates of the aboveground biomass of the mangroves of northeastern Brazil, considering that the models developed in this study are more representative in terms of size range and have better fits and greater precision than those previously presented. These models may also be applied to mangroves in similar environment settings that present similar structural and architectural features to that of $R$. mangle in our study area. 

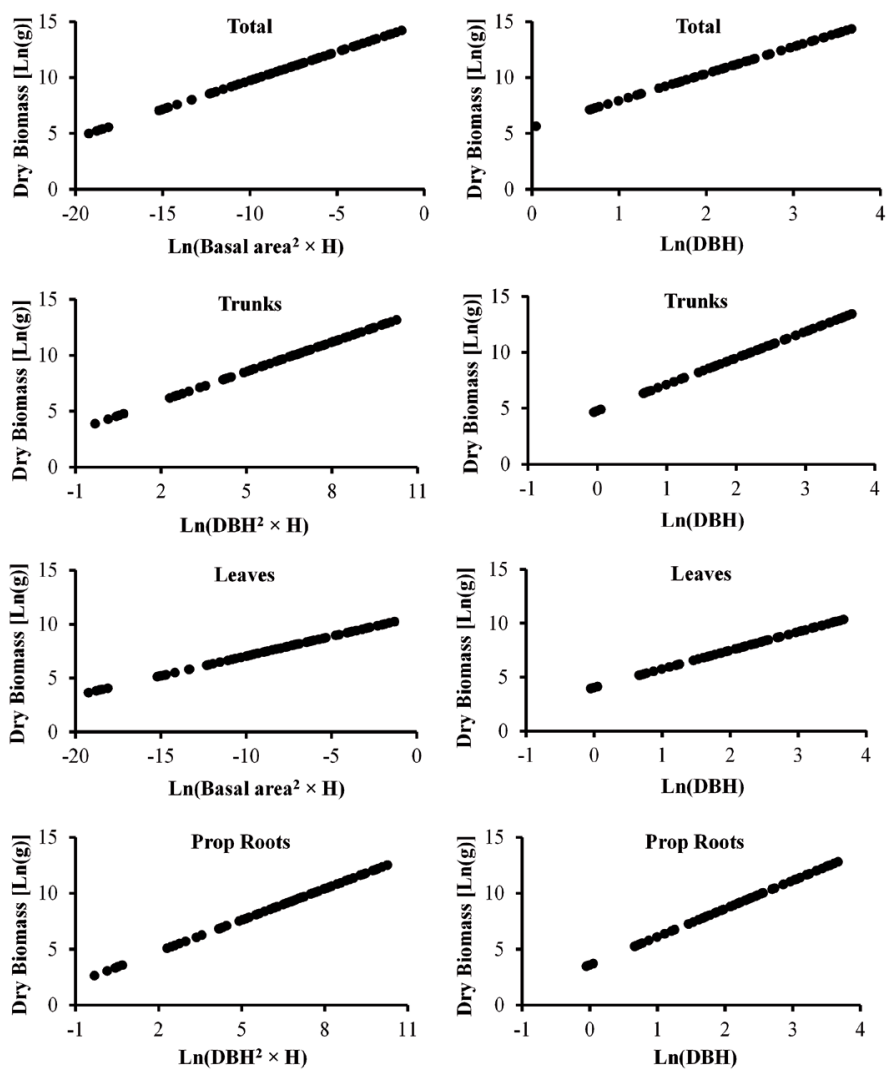

Figure 4. Graphical dispersions of the best log-transformed equations and the alternative DBH-only equations for the main dependent variables (Total biomass; Trunks; Leaves; and Prop Roots).

Table 4. Best allometric models for estimation of the aboveground biomass of $R$. mangle. Legend: $\mathrm{H}=$ height; $\mathrm{n}=\mathrm{sample}$ number; $a$ and $b=$ intercept and coefficient of regression, respectively; $\mathrm{R}^{2}=$ adjusted coefficient of determination; $\mathrm{F}=\mathrm{ANOVA}$ $F$ value; SEE - standard error of estimation.

\begin{tabular}{|c|c|c|c|c|c|c|c|}
\hline Model & Compartment & $\mathrm{n}$ & a & $\mathrm{b}$ & $\mathrm{R}_{\mathrm{a}}^{2}$ & $\mathrm{~F}$ & SEE \\
\hline $\operatorname{Ln}($ biomass $)=a+b \operatorname{Ln}\left(\mathrm{DBH}^{2} \times \mathrm{H}\right)$ & Trunk & 74 & 4.160747 & 0.875996 & 0.98 & 3179.580 & 0.349 \\
\hline $\operatorname{Ln}($ biomass $)=\mathrm{a}+\mathrm{b} \operatorname{Ln}\left[\mathrm{DBH}^{2}+\mathrm{H}+\left(\mathrm{DBH}^{2} \times \mathrm{H}\right)\right]$ & Main branches & 60 & 1.914396 & 0.891536 & 0.85 & 342.9470 & 0.769 \\
\hline Ln (biomass) $=a+b \operatorname{Ln}(\mathrm{DBH})$ & Branches & 64 & 3.157351 & 2.638149 & 0.92 & 746.0843 & 0.547 \\
\hline $\operatorname{Ln}($ biomass $)=\mathrm{a}+\mathrm{b} \operatorname{Ln}\left(\right.$ Basal $\left.^{2} \operatorname{rre}^{2} \times \mathrm{H}\right)$ & Twigs & 74 & 11.309867 & 0.420531 & 0.95 & 1343.560 & 0.447 \\
\hline 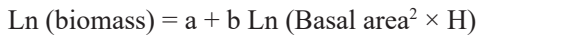 & Leaves & 74 & 10.712324 & 0.366420 & 0.94 & 1197.919 & 0.413 \\
\hline $\operatorname{Ln}($ biomass $)=a+b \operatorname{Ln}(\mathrm{DBH})$ & $\begin{array}{l}\text { Reproductive } \\
\text { parts }\end{array}$ & 43 & -0.456055 & 2.119786 & 0.43 & 32.06745 & 1.560 \\
\hline $\operatorname{Ln}($ biomass $)=a+b \operatorname{Ln}\left(\mathrm{DBH}^{2} \times \mathrm{H}\right)$ & Prop roots & 74 & 2.939739 & 0.934209 & 0.96 & 1799.216 & 0.494 \\
\hline Ln $($ biomass $)=a+b \operatorname{Ln}\left(\right.$ Basal area $\left.{ }^{2} \times H\right)$ & Total & 74 & 14.86763 & 0.51320 & 0.99 & 7313.432 & 0.234 \\
\hline Ln (biomass) $=\mathrm{a}+\mathrm{b} \operatorname{Ln}\left(\right.$ Basal $\left.^{2} \operatorname{area}^{2} \times \mathrm{H}\right)$ & Green parts & 74 & 10.805191 & 0.372766 & 0.94 & 1159.572 & 0.427 \\
\hline $\operatorname{Ln}($ biomass $)=a+b \operatorname{Ln}\left(\right.$ Basal $\left.\operatorname{area}^{2} \times H\right)$ & Aerial parts & 74 & 14.599081 & 0.507845 & 0.99 & 7007.320 & 0.237 \\
\hline $\operatorname{Ln}($ biomass $)=a+b \operatorname{Ln}\left(\right.$ Basal $\left.\operatorname{area}^{2} \times H\right)$ & Crown 1 & 74 & 11.761324 & 0.395483 & 0.95 & 1476.419 & 0.401 \\
\hline $\operatorname{Ln}($ biomass $)=a+b \operatorname{Ln}(\mathrm{DBH})$ & Crown 2 & 74 & 4.409862 & 2.346133 & 0.97 & 2412.159 & 0.397 \\
\hline $\operatorname{Ln}($ biomass $)=\mathrm{a}+\mathrm{b} \operatorname{Ln}\left(\right.$ Basal $\left.\operatorname{area}^{2} \times \mathrm{H}\right)$ & Crown 3 & 74 & 13.753848 & 0.507336 & 0.97 & 2472.099 & 0.398 \\
\hline 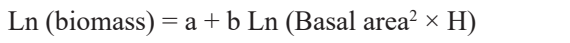 & Woody parts & 74 & 14.898165 & 0.526360 & 0.99 & 7365.104 & 0.239 \\
\hline $\operatorname{Ln}($ biomass $)=\mathrm{a}+\mathrm{b} \operatorname{Ln}\left(\mathrm{DBH}^{2} \times \mathrm{H}\right)$ & $\begin{array}{l}\text { Trunks + Main } \\
\text { branches }\end{array}$ & 74 & 4.230779 & 0.886335 & 0.98 & 4161.717 & 0.308 \\
\hline
\end{tabular}


Table 5. Allometric models to estimate the aboveground biomass of $R$. mangle considering only DBH as the independent variable. Legend: $n=$ sample number; $a$ and $b=$ intercept and coefficient of regression, respectively; $R_{a}^{2}=$ adjusted coefficient of determination; $\mathrm{F}=\mathrm{ANOVA} F$ value; $\mathrm{SEE}$ - standard error of estimation.

\begin{tabular}{|c|c|c|c|c|c|c|c|}
\hline Model & Compartiment & $\mathrm{n}$ & a & $\mathrm{b}$ & $\mathrm{R}_{\mathrm{a}}^{2}$ & $\mathrm{~F}$ & SEE \\
\hline $\operatorname{Ln}($ biomass $)=a+b \operatorname{Ln}(\mathrm{DBH})$ & Trunk & 74 & 4.775321 & 2.359246 & 0.97 & 2418.645 & 0.398 \\
\hline $\operatorname{Ln}($ biomass $)=a+b \operatorname{Ln}(\mathrm{DBH})$ & Main branches & 60 & 3.127223 & 2.208690 & 0.85 & 326.9456 & 0.785 \\
\hline $\operatorname{Ln}($ biomass $)=a+b \operatorname{Ln}(\mathrm{DBH})$ & Twigs & 74 & 3.659714 & 1.971528 & 0.95 & 1259.326 & 0.461 \\
\hline $\operatorname{Ln}($ biomass $)=a+b \operatorname{Ln}(\mathrm{DBH})$ & Leaves & 74 & 4.043293 & 1.719390 & 0.94 & 1165.037 & 0.418 \\
\hline $\operatorname{Ln}($ biomass $)=a+b \operatorname{Ln}(\mathrm{DBH})$ & Prop roots & 74 & 3.604243 & 2.511704 & 0.95 & 1415.349 & 0.555 \\
\hline $\operatorname{Ln}($ biomass $)=a+b \operatorname{Ln}(\mathrm{DBH})$ & Total & 74 & 5.534244 & 2.404770 & 0.99 & 5039.404 & 0.281 \\
\hline $\operatorname{Ln}($ biomass $)=a+b \operatorname{Ln}(\mathrm{DBH})$ & Green parts & 74 & 4.020093 & 1.749435 & 0.94 & 1134.368 & 0.431 \\
\hline $\operatorname{Ln}($ biomass $)=a+b \operatorname{Ln}(\mathrm{DBH})$ & Aerial parts & 74 & 5.360943 & 2.380682 & 0.99 & 5189.110 & 0.274 \\
\hline $\operatorname{Ln}($ biomass $)=a+b \operatorname{Ln}(\mathrm{DBH})$ & Crwon 1 & 74 & 4.564397 & 1.855256 & 0.95 & 1411.040 & 0.410 \\
\hline $\operatorname{Ln}($ biomass $)=a+b \operatorname{Ln}(\mathrm{DBH})$ & Crwon 3 & 74 & 4.516360 & 2.382390 & 0.97 & 2461.897 & 0.399 \\
\hline $\operatorname{Ln}($ biomass $)=a+b \operatorname{Ln}(\mathrm{DBH})$ & Woody parts & 74 & 5.326837 & 2.465755 & 0.99 & 4867.384 & 0.294 \\
\hline $\operatorname{Ln}($ biomass $)=a+b \operatorname{Ln}(\mathrm{DBH})$ & Trunks + Main branches & 74 & 4.852192 & 2.387289 & 0.98 & 2972.973 & 0.364 \\
\hline
\end{tabular}

\section{ACKNOWLEDGEMENTS}

This work was supported through a research grant conceded from PETROBRAS - Petróleo Brasileiro to Francisco Sandro Rodrigues Hollanda.

\section{REFERENCES}

ABOHASSAN, R. A. A.; OKIA, C. A.; AGEA, J. G.; KIMOND, J. M.; MCDONALD, M. M. Perennial biomass production in arid mangrove system on the red sea cost of Saudi Arabia. Environ. Res. J., v. 6, n. 1, p. 22-31, 2012.

ALONGI, D. M. Paradigm shifts in mangrove biology. In: PERILLO, G.; WOLANSKI, E.; CAHOON, D.; BRINSON, M. (Eds.). Coastal wetlands: An integrated ecosystem approach. Amsterdam: Elsevier, 2009. p. 615-634.

BROWN, S. Measuring carbon in forests: current status and future challenges. Environ. Pollut., v. 116, n. 3, p. 363-372, 2002.

BROWN, S.; GILleSPIE, A. J. R.; LUGO, A. E. Biomass estimation methods for tropical forests with applications to forest inventory data. For. Sci., v. 35, n. 4, p. 881-902, 1989.

BROWN S.; SCHROEDER, P.; BIRDSEY, R. Aboveground biomass distribution of US eastern hardwood forests and the use of large trees as an indicator of forest development. For. Ecol. Manag., v. 96, n. 1-2, p. 37-47, 1997.

BURGER, D. M.; DELITTI, W. B. C. Allometric models for estimating the phytomass of a secondary Atlantic Forest area of southeastern Brazil. Biota Neotrop., v. 8, n. 4, p. 131-136, 2008.

CHANDRA, I. A.; SECA, G.; HENA, M. K. A. Aboveground biomass production of Rhizophora apiculata Blume in Sarawak mangrove forest. Am. J. Agric. Biol. Sci., v. 6, n. 4, p. 469-474, 2011.

CLOUGH, B. F.; SCOTT, K. Allometric relationships for estimating above-ground biomass in six mangrove species. For. Ecol. Manag., v. 27, n. 2, p. 117-127, 1989.
COMLEY, B. W. T.; MCGUINNESS, K. A. Above- and belowground biomass, and allometry of four common northern Australian mangroves. Aust. J. Bot., v. 53, n. 5, p. 431-436, 2005.

COX, E. F.; ALLEN, J. A. Stand structure and productivity of the introduced Rhizophora mangle in Hawaii. Estuaries, v. 22, n. 2, p. 276-284, 1999.

DONATO, D. C.; KAUFFMAN, J. B.; MURDIYARSO, D.; KURNIANTO, S.; STIDHAM, M.; KANNINEN, M. Mangroves among the most carbon-rich forests in the tropics. Nat. Geosci., v. 4, p. 293-297, 2011.

DRAPER, N. R.; SMITH, H. Applied Regression Analysis. $3^{\text {rd }}$ ed. New York: John Wiley and Sons, 1998. 736 p.

DUKE, N. C. Mangrove Floristics and Biogeography. In: ROBERTSON, A. I.; ALONGI, D. M. (Eds.). Tropical Mangrove Ecosystems, Coastal and Estuarine Studies 41. Washington: American Geophysical Union Press, 1992. p. $63-$ 100 .

DUKE, N. C.; LO, E.; SUN, M. Global distribution and genetic discontinuities of mangroves - emerging patterns in the evolution of Rhizophora. Trees, v. 16, n. 2, p. 65-79, 2002.

ESTRADA, G. C. D.; SOARES, M. L. G.; SANTOS, D. M. C.; FERNANDEZ, V.; ALMEIDA, P. M. M.; ESTEVAM, M. R. M.; MACHADO, M. R. O. Allometric models for aboveground biomass estimation of the mangrove Avicennia schaueriana. Hydrobiologia, v. 734, n. 1, p. 171-185, 2014.

FERNANDES, M. E. B. Phenological patterns of Rhizophora L., Avicennia L. and Laguncularia Gaertn. F. in Amazonian mangrove swamps. Hydrobiologia, v. 413, p. 53-62, 1999.

FROMARD, F.; PUIG, H.; MOUGIN, E.; MARTY, G.; BETOULLE, J. L.; CADAMURO, L. Structure, above-ground biomass and dynamics of mangrove ecosystems: new data from French Guiana. Oecologia, v. 115, n. 1, p. 39-53, 1998.

HOSSAIN, M.; OTHMAN, S.; BUJANG, J. S.; KUSNAN, M. Net primary productivity of Bruguiera parviflora (Wight \& Arn.) dominated mangrove forest at Kuala Selangor, Malaysia. For. Ecol. Manag., v. 255, n. 1, p. 179-182, 2008. 
KOMIYAMA, A.; ONG, J. E.; POUNGPARN, S. Allometry, biomass, and productivity of mangrove forests: A review. Aquat. Bot., v. 89, n. 2, p. 128-137, 2008.

LU, D.; MAUSEL, P.; BRONDIZIO, E.; MORAN, E. Assessment of atmospheric correction methods for Landsat TM data applicable to Amazon basin LBA research. Int. J. Remote. Sens., v. 23, n. 13, p. 2651-2671, 2002.

MCLEOD, E.; CHIMURA, G. L.; BOUILLON, S.; SALM, R.; BJÖRK, M.; DUARTE, C. M.; LOVELOCK, C. E.; SCHLESINGER, W. H.; SILLIMAN, B. R. A blueprint for blue carbon: toward an improved understanding of the role of vegetated coastal habitats in sequestering $\mathrm{CO}_{2}$. Front. Ecol. Environ., v. 9, n. 10, p. 552-560, 2011.

MEDEIROS, T. C. C.; SAMPAIO, E. V. S. B. Allometry of aboveground biomasses in mangrove species in Itamaracá, Pernambuco, Brazil. Wetl. Ecol. Manag., v. 16, n. 4, p. 323330,2008 .

MURALI, K. S.; BHAT, D. M.; RAVINDRANATH, N. H. Biomass estimation equations for tropical deciduous and evergreen forests. Int. J. Agric. Resour. Gov. Ecol., v. 4, n. 1, p. 81-92, 2005.

ONG, J. E.; GONG, W. K.; WONG, C. H. Allometry and partitioning of the mangrove, Rhizophora apiculata. For. Ecol. Manag., v. 188, n. 1-3, p. 395-408, 2004.

ONYEKWELU, J. C. Above-ground biomass production and biomass equations for even-aged Gmelina arborea (ROXB) plantations in south-western Nigeria. Biom. Bioen., v. 26, n. 1, p. 39-46, 2004.

ROSS, M. S.; RUIZ, P. L.; TELESNICKI, G. J.; MEEDER, J. F. Estimating above-ground biomass and production in mangrove communities of Biscayne National Park, Florida (U.S.A.). Wetl. Ecol. Manag., v. 9, n. 1, p. 27-37, 2001.

SAH, J. P.; ROSS, M. S.; KOPTUR, S.; SNYDER, J. R. Estimating aboveground biomass of broadleaved woody plants in the understory of Florida Keys pine forests. For. Ecol. Manag., v. 203, n. 1-3, p. 319-329, 2004.

SAMPAIO, E.; GASSON, P.; BARACAT, A.; CUTLER, D.; PAREYN, F.; LIMA, K. C. Tree biomass estimation in regenerating areas of tropical dry vegetation in northeast Brazil. For. Ecol. Manag., v. 259, n. 6, p. 1135-1140, 2010.
SANTOS, T. O.; ANDRADE, K. V. S.; SANTOS, H. V. S.; CASTANEDA, D. A. F. G.; SANTANA, M. B. S.; HOLANDA, F. S. R.; SANTOS, M. J. C. Caracterização estrutural de bosques de mangue: Estuário do rio São Francisco. Sci. Plena, v. 8, n. 4, p. 1-7, 2012.

SCHAEFFER-NOVELLI, Y.; CITRÓN, G. Guia para estudo de áreas de manguezal: estrutura, função e flora. São Paulo: Caribbean Ecological Research, 1986. 150 p.

SHERMAN, R. E.; FAHEY, T. J.; MARTINEZ, P. Spatial patterns of biomass and aboveground net primary productivity in a mangrove ecosystem in the Dominican Republic. Ecosystems, v. 6, n. 4, p. 384-398, 2003.

SIIKAMÄKI, J.; SANCHIRICO, J. N.; JARDINE, S. L. Global economic potential for reducing carbon dioxide emissions from mangrove loss. Proc. Natl. Acad. Sci. U.S.A., v. 109, n. 36, p. 14369-14374, 2012.

SILVEIRA, P.; KOEHLER, H. S.; SANQUETTA, C. R.; ARCE, J. E. O estado da arte na estimativa de biomassa e carbono em formações florestais. Floresta, v. 38, n. 1, p. 185-206, 2007.

SMITH III, T. J.; WHELAN, K. R. T. Development of allometric relations for three mangrove species in South Florida for use in the Greater Everglades Ecosystem restoration. Wetl. Ecol. Manag., v. 14, n. 5, p. 409-419, 2006.

SOARES, M. L. G.; SCHAEFFER-NOVELLI, Y. Above-ground biomass of mangrove species. I. Analysis of models. Estuar. Coast. Shelf Sci., v. 65, n. 1-2, p. 1-18, 2005.

SOARES, M. L. G.; ESTRADA, G. C. D.; FERNANDEZ, V.; TOGNELLA, M. M. P. Southern limit of the Western South Atlantic mangroves: Assessment of the potential effects of global warming from a biogeographical perspective. Estuar. Coast. Shelf Sci., v. 101, p. 44-53, 2012.

TAMOOH, F.; KAIRO, J. G.; HUXHAM, M.; KIRUI, B.; MENCUCCINI, M.; KARACHI, M. Biomass accumulation in a rehabilitated mangrove forest at Gazi Bay. In: HOORWEG, J.; MUTHIGA, N. (Eds.). Advances in Coastal - People, process and ecosystems in Kenya. Leiden: African Studies Centre, 2009. p. 138-147.

TWILLEY, R. R.; CHEN, R. H.; HARGIS, T. Carbon sinks in mangroves and their implications to carbon budget of tropical coastal ecosystems. Water Air Soil Pollut., v. 64, n. 1, p. 265-288, 1992.

ZAR, J. H. Biostatistical Analysis. $5^{\text {th }}$ ed. London: Pearson, 2010. 